\title{
Expression of PKC-beta or cyclin D2 predicts for inferior survival in diffuse large B-cell lymphoma
}

\author{
Christine P Hans ${ }^{1}$, Dennis D Weisenburger ${ }^{1}$, Timothy C Greiner ${ }^{1}$, Wing C Chan ${ }^{1}$, \\ Patricia Aoun ${ }^{1}$, Gregory T Cochran ${ }^{1}$, Zenggang Pan ${ }^{1}$, Lynette M Smith ${ }^{2}$, James C Lynch ${ }^{2}$, \\ Robert Gregory Bociek ${ }^{3}$, Philip J Bierman ${ }^{3}$, Julie M Vose ${ }^{3}$ and James O Armitage ${ }^{3}$ \\ ${ }^{1}$ Department of Pathology and Microbiology, University of Nebraska Medical Center, Omaha, NE, USA, \\ ${ }^{2}$ Department of Preventive and Societal Medicine, University of Nebraska Medical Center, Omaha, NE, USA \\ and ${ }^{3}$ Department of Internal Medicine, University of Nebraska Medical Center, Omaha, NE, USA
}

\begin{abstract}
We sought to determine whether identification of poor-risk subgroups of diffuse large B-cell lymphoma (DLBCL) using immunohistochemical stains would have practical utility with regard to prognosis and therapeutic decisions. Tissue microarray blocks were created using replicate samples of formalin-fixed, paraffin-embedded tissue from 200 cases of de novo DLBCL. The sections were stained with antibodies to proteins that are expressed by activated or proliferating B cells including MUM1, FOXP1, bcl-2, survivin, protein kinase C-beta (PKC- $\beta$ ), cyclin D2, cyclin D3, and Ki-67. In univariate analysis, tumor expression of cyclin D2 $(P=0.025)$ or $P K C-\beta(P=0.015)$ was associated with a worse overall survival, whereas none of the other markers was predictive of overall survival. Patients with DLBCL that expressed either cyclin D2 or PKC- $\beta$ had a 5-year overall survival of only $30 \%$ as compared to $52 \%$ for those who were negative for both markers $(P=0.0019)$. In multivariate analysis, the expression of cyclin D2 or PKC- $\beta$ was an independent predictor of poor overall survival $(P=0.035)$. Cyclin D2 and PKC- $\beta$ expression will be useful in designing a 'biological prognostic index' for patients with DLBCL.
\end{abstract}

Modern Pathology (2005) 18, 1377-1384. doi:10.1038/modpathol.3800434; published online 13 May 2005

Keywords: diffuse large B-cell lymphoma; immunohistochemistry; cyclin D2; protein kinase C-beta

Diffuse large B-cell lymphoma (DLBCL) accounts for $30-40 \%$ of all new diagnoses of non-Hodgkin's lymphoma. ${ }^{1,2}$ However, durable remissions are achieved in only $40-50 \%$ of patients with DLBCL despite the use of anthracycline-based chemotherapy. ${ }^{2}$ The addition of rituximab to standard chemotherapy appears to improve the survival of patients with DLBCL expressing bcl-2. ${ }^{3}$ The prognosis of patients with DLBCL is currently estimated using the clinical parameters of the International Prognostic Index (IPI), but these clinical parameters are likely to be surrogates for underlying biological differences. ${ }^{4}$ Therefore, it is important to find biological markers at the time of diagnosis that

Correspondence: Dr C P Hans, MD, Department of Pathology and Microbiology, 983135 Nebraska Medical Center, Omaha, NE 68198-3135, USA.

E-mail: chans@unmc.edu

The results of this study were presented in part at the Annual Meeting of the United States and Canadian Academy of Pathology, March 2003, in Washington, DC.

Received 6 February 2005; revised and accepted 29 March 2005; published online 13 May 2005 will identify patients who may benefit from more aggressive or experimental therapies.

Recent studies have demonstrated that DLBCL can be divided into prognostically important subgroups by gene expression profiling using cDNA or oligonucleotide microarrays. ${ }^{5-9}$ Four subgroups, identified as germinal center B-cell-like, activated B-cell-like, primary mediastinal, and unclassified DLBCL have been delineated using cDNA microarrays. ${ }^{5,7,8,10}$ The germinal center B-cell-like and primary mediastinal subgroups are reported to have a significantly better survival than the activated B-cell-like and unclassified subgroups..$^{5,7,8,10}$ Alternatively, DLBCL can be divided into two molecularly distinct subgroups of cured and fatal/refractory DLBCL. ${ }^{6}$ Since this microarray technology is expensive and not generally available, a simpler and more widely available method to identify those patients with aggressive or refractory disease would have wide applicability and practical utility in routine clinical practice. The goal of this study was to identify poor-risk subgroups of DLBCL using immunohistochemical stains for biologic markers that may be associated with aggressive disease. 


\section{Patients and methods}

We studied 200 adult patients in the Nebraska Lymphoma Study Group Registry with de novo DLBCL, available archival tissue, and at least 1 year of follow-up for surviving patients. The median follow-up of the surviving patients was 7.7 years (range, 1.3-19.6 years). Each patient was evaluated and staged according to a standard protocol and all patients were treated with curative intent. Therapy for 110 patients $(55 \%)$ consisted of combination chemotherapy including cyclophosphamide, doxorubicin or mitoxantrone, procarbazine, bleomycin, vincristine, and prednisone or dexamethasone (CAP-BOP), ${ }^{11}$ whereas 85 patients $(42 \%)$ received cyclophosphamide, mitoxantrone, vincristine, prednisone (CNOP), ${ }^{12}$ and five patients $(3 \%)$ received radiation therapy for localized disease. No patient received rituximab as part of the initial chemotherapy regimen. The University of Nebraska Medical Center Institutional Review Board approved this study and informed consent was obtained in all cases.

To evaluate biological markers, we created tissue microarrays containing representative tissue from each case. To create each tissue microarray, hematoxylin and eosin-stained sections from each paraffin-embedded, formalin-fixed block were reviewed to define diagnostic areas. From these diagnostic areas, four random, representative $0.6 \mathrm{~mm}$ cores were obtained from each case and inserted in a grid pattern into a recipient paraffin block using a tissue arrayer (Beecher Instruments, Silver Spring, MD, USA). Five micrometer sections were cut from each tissue microarray and stained with antibodies to MUM1, FOXP1, bcl-2, survivin, protein kinase C-beta (PKC- $\beta$ ), cyclin D2, cyclin D3, and Ki-67 (Table 1). These antibodies were selected because they are applicable to paraffin-embedded tissue and the corresponding proteins are expressed by activated or proliferating $\mathrm{B}$ cells, including some proteins associated with the activated B-cell-like gene expression signature. ${ }^{5,7}$ Following deparaffinization, heat-induced antigen retrieval techniques were employed for each antibody (Table 1). An amplification kit (Ventana Medical Systems, Tucson, AZ, USA) was used to enhance staining for FOXP1, survivin, PKC- $\beta$ and cyclin D3. Following antigen retrieval and primary antibody incubation, the reaction was completed in a Ventana ES instrument using a diaminobenzidine immunoperoxidase detection kit (Ventana). A CD20 stain was also performed to evaluate each core for involvement by tumor. Each core was evaluated by visual estimation for the percentage of tumor cells positive with each antibody and the findings were recorded in $10 \%$ increments. For each case, the core with the highest percentage of tumor cells stained was used for analysis. A survival tree method was used to evaluate all possible cut-points for statistical significance. ${ }^{13}$ The intensity of staining was not used in
Table 1 Antibodies used for immunohistochemical staining of DLBCL

\begin{tabular}{|c|c|c|c|c|}
\hline Antibody & Clone & Source & $\begin{array}{l}\text { Antigen } \\
\text { retrieval }\end{array}$ & Dilution \\
\hline CD20 & L26 & $\begin{array}{l}\text { Dako, Carpinteria, } \\
\text { CA, USA }\end{array}$ & Citrate 30 & $1: 200$ \\
\hline MUM1 & MUM1p $^{a}$ & Falini $^{(58)}$ & EDTA 30 & $1: 10$ \\
\hline FOXP1 & JC12 & Banham $^{(59)}$ & EDTA 30 & $1: 80$ \\
\hline Bcl-2 & 124 & $\begin{array}{l}\text { Dako, Carpinteria, } \\
\text { CA, USA }\end{array}$ & EDTA 30 & $1: 10$ \\
\hline Survivin & Polyclonal & $\begin{array}{l}\text { Novus Biologicals, } \\
\text { Littleton, CO, USA }\end{array}$ & Citrate 10 & $1: 500$ \\
\hline PKC- $\beta$ & 28 & Serotec, Oxford, UK & EDTA 30 & $1: 75$ \\
\hline Cyclin D2 & Polyclonal & $\begin{array}{l}\text { Santa Cruz } \\
\text { Biotechnology, Santa } \\
\text { Cruz, CA, USA }\end{array}$ & EDTA 30 & $1: 500$ \\
\hline Cyclin D3 & DCS-22 & $\begin{array}{l}\text { NeoMarkers, } \\
\text { Fremont, CA, USA }\end{array}$ & Citrate 10 & $1: 100$ \\
\hline Ki-67 & Polyclonal & $\begin{array}{l}\text { Dako, Carpinteria, } \\
\text { CA, USA }\end{array}$ & Citrate 60 & $1: 20$ \\
\hline
\end{tabular}

Citrate 10 indicates $10 \mathrm{~min}$ at $114^{\circ} \mathrm{C}$ in a pressure cooker in citrate $(10 \mathrm{mM}, \mathrm{pH} 6.0)$, Citrate 30 indicates $30 \mathrm{~min}$ at $95^{\circ} \mathrm{C}$ in citrate $(10 \mathrm{mM}$, $\mathrm{pH}$ 6.0), Citrate 60 indicates $60 \mathrm{~min}$ at $95^{\circ} \mathrm{C}$ in citrate $(10 \mathrm{mM}, \mathrm{pH} 6.0)$, EDTA 30 indicates $30 \mathrm{~min}$ at $95^{\circ} \mathrm{C}$ in EDTA ( $1 \mathrm{mM}, \mathrm{pH} 8.0$ ).

${ }^{\mathrm{a}}$ This clone is now commercially available from Dako.

the determination of positivity since differences in fixation and processing may result in variable staining. Cases were considered positive if $30 \%$ or more of the tumor cells were stained, except for PKC- $\beta$ and Ki-67 for which a cutoff of greater than $50 \%$ was used. As the survival tree method did not yield more informative cutoffs, the $30 \%$ cut-point was chosen based on a prior analysis of some of the markers. ${ }^{14,15}$ In addition, others have used similar cutoffs with tissue microarrays or whole sections. ${ }^{16,17}$ A cutoff of greater than $50 \%$ was chosen for PKC- $\beta$ because this value was found to be the most informative using the survival tree method. There is no consensus in the literature regarding the best cut-point for Ki-67 and the survival tree method did not yield an informative cut-point; therefore, we chose $50 \%$, which was the mean Ki-67 expression in our study population.

Fisher's exact test was used to compare the clinical characteristics of the patients. Median ages were compared using the Wilcoxon rank-sum test. The Kaplan-Meier method was used to estimate overall and event-free survival distributions. ${ }^{18}$ Overall survival was calculated as the time from diagnosis to the date of death or last contact. Patients who were alive at last contact were treated as censored for overall survival analysis. Event-free survival was calculated from the time of diagnosis to the date of progression, death, or last contact. Patients who were alive at last contact and had not progressed were treated as censored for event-free survival analysis. The log-rank test was used to compare survival distributions. Multivariate analysis was performed using the Cox regression method. ${ }^{19}$ Stepwise selection was employed to determine 
the variables that were independent predictors of overall survival using a significance level of $P=0.05$. SAS software (SAS Institute Inc, Cary, NC, USA) was employed for the data analysis.

\section{Results}

Clinical data were available for all patients. The patients consisted of 94 men and 106 women with a median age of 69 years (range, 19-93 years). The median follow-up of the surviving patients was 7.7 years (range, 1.3-19.6 years). The 5-year overall survival for the entire group was $44 \%$ and the 5 -year event-free survival was $35 \%$.

Expression of cyclin D2 was seen in 19\% (38/200) of the cases, PKC- $\beta$ in $22 \%$ (41/187), MUM1 in $45 \%$ (89/200), bcl-2 in 58\% (115/200), FOXP1 in $61 \%$ (119/196), Ki-67 in 62\% (119/193), cyclin D3 in 62\% $(122 / 197)$, and survivin in 65\% (125/193). Univariate analysis of the expression of each protein and its relationship to overall survival and event-free survival was performed. Tumor expression of cyclin D2 (Figure 1a) was associated with a significantly shorter overall survival $(P=0.025$; Figure 2a) and event-free survival $(P=0.07)$. Similarly, PKC- $\beta$ expression (Figure 1b) predicted for worse overall survival $(P=0.015$; Figure $2 \mathrm{~b})$ and event-free survival $(P=0.04)$. Cases with tumor expression of MUM1 demonstrated a trend toward worse overall survival, but this did not reach statistical significance $(P=0.18)$. None of the other proteins were predictive of overall survival or event-free survival.

There was little overlap in the expression of cyclin D2 and PKC- $\beta$ in DLBCL. Of the 71 cases positive for either cyclin D2 or PKC- $\beta$, only eight cases were positive for both markers. Therefore, we combined the results of these two stains to determine survival outcomes. The combination of either PKC- $\beta$ or cyclin D2 positivity predicted for significantly worse overall survival $(P=0.002$; Figure 3 a) and event-free survival $(P=0.012$; Figure $3 \mathrm{~b})$. All eight patients expressing both cyclin D2 and PKC- $\beta$ died with a median overall survival of only 16 months, which is similar to the median overall survival of 15 months for those expressing either cyclin D2 or PKC- $\beta$. A comparison of the clinical characteristics of cases expressing cyclin D2 or PKC$\beta$ to those who were negative for both markers is shown in Table 2. There were no significant differences in IPI scores or the components that comprise the IPI score between these two groups. However, patients who were positive for PKC- $\beta$ or cyclin D2 were more likely to have B symptoms than those who were negative for both markers. When evaluating the expression of PKC- $\beta$ or cyclin D2 within the context of IPI scores, these two markers added prognostic value to the IPI score. Patients with low IPI scores (0-2) who expressed PKC- $\beta$ or cyclin D2 had a significantly worse overall survival $(P=0.037$, Figure 4a) compared to those lacking
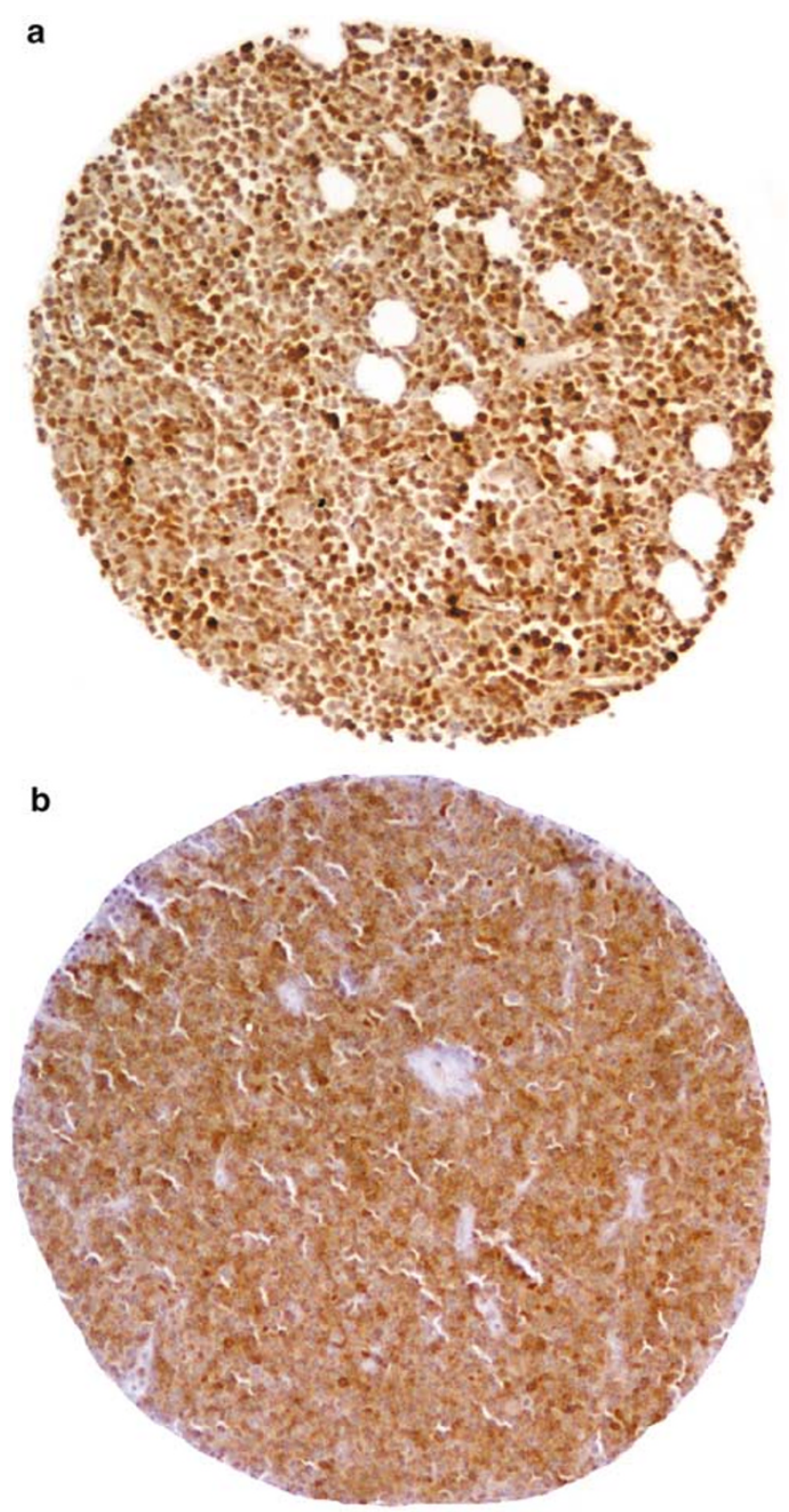

Figure 1 Immunoperoxidase staining. (a) Nuclear expression of cyclin D2 ( × 100); (b) cytoplasmic expression of PKC- $\beta(\times 100)$.

both markers. A similar trend was observed for patients with high IPI scores (3-5) who expressed PKC- $\beta$ or cyclin D2 $(P=0.10$, Figure $4 \mathrm{~b})$, however, this did not reach statistical significance.

Multivariate analysis was performed and stepwise selection was employed to determine the variables that were independent predictors of overall survival. Variables considered in the analysis were the IPI risk groups (0-2 and 3-5), the expression of PKC- $\beta$ or cyclin D2, and expression of each of the other proteins studied. In addition to a high IPI score, the expression of PKC- $\beta$ or cyclin D2 was a significant independent predictor of worse overall survival. The risk of death was 2.6 times (95\% CI, 1.8-3.7) 

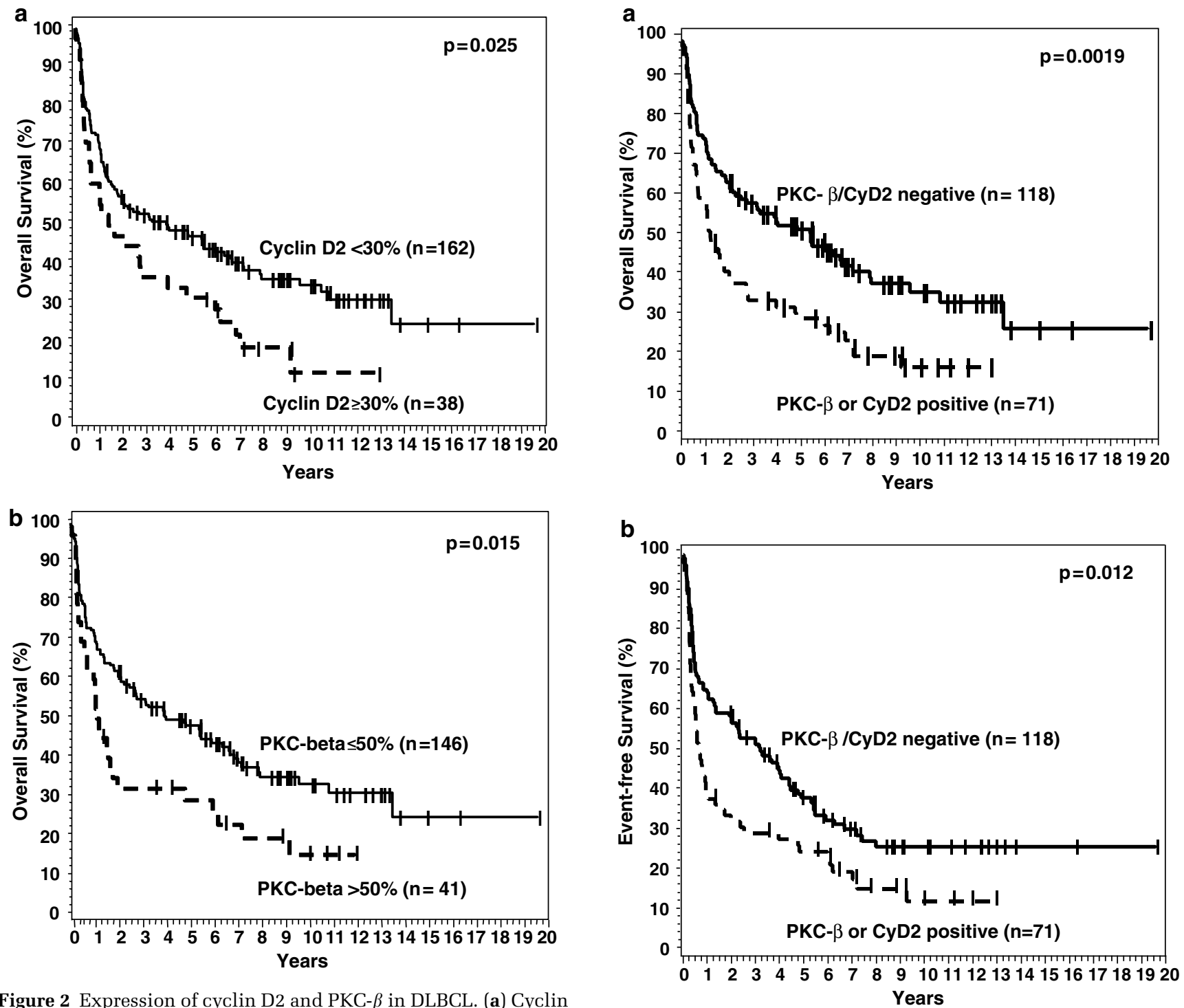

Figure 2 Expression of cyclin D2 and PKC- $\beta$ in DLBCL. (a) Cyclin D2 expression and overall survival; (b) PKC- $\beta$ expression and overall survival.

greater for patients with a high IPI score $(P<0.0001)$ and 1.6 times (95\% CI, 1.1-2.3) greater for those expressing PKC- $\beta$ or cyclin D2 $(P=0.018)$.

\section{Discussion}

The identification at the time of diagnosis of patients with DLBCL who are likely to have a poor prognosis could have an important impact on therapeutic decisions. The use of aggressive or experimental treatments might lead to better outcomes for this group of patients. Although prognostic subgroups of DLBCL have been identified using cDNA or oligonucleotide microarrays, this technology is currently not available for routine clinical use. ${ }^{5-7}$ In addition, this method requires the use of fresh or frozen tumor tissue, which is often not

Figure 3 Expression of either PKC- $\beta$ or cyclin D2 (CyD2) in DLBCL. (a) Relationship to overall survival; (b) relationship to event-free survival.

available. On the other hand, immunohistochemical stains are routinely used by pathologists for diagnosis. Therefore, the use of immunohistochemical stains to identify patients with a poor prognosis would have practical utility for the initial management of patients with DLBCL.

Using a panel of immunostains, we sought to identify a group of patients with DLBCL who had poor overall survival and event-free survival. Our selection of the individual antibodies was based on data derived from gene expression studies ${ }^{5-7}$ and reports in the literature. ${ }^{20-22}$ We found that tumor expression of PKC- $\beta$ or cyclin D2 was significantly associated with a poor outcome in DLBCL. Patients expressing either marker had a median overall survival of only 15 months as compared to 65 
Table 2 Clinical features of patients with DLBCL expressing cyclin D2 or PKC- $\beta$ (positive) compared to those lacking both markers (negative)

\begin{tabular}{|c|c|c|c|c|}
\hline & Total $^{\mathrm{a}}$ & Positive & Negative & $\mathrm{P}$ value \\
\hline Total number & 200 & 71 & 118 & \\
\hline \multicolumn{5}{|l|}{ Sex } \\
\hline Male & $94(47 \%)$ & $36(51 \%)$ & $55(47 \%)$ & 0.65 \\
\hline Female & $106(53 \%)$ & $35(49 \%)$ & $63(53 \%)$ & \\
\hline \multicolumn{5}{|l|}{ Age (years) } \\
\hline Median & 69 & 69 & 69 & $0.07^{\mathrm{b}}$ \\
\hline Range & $19-93$ & $19-92$ & $19-93$ & \\
\hline \multicolumn{5}{|l|}{ Stage } \\
\hline I/II & $114(58 \%)$ & $36(51 \%)$ & $71(61 \%)$ & 0.23 \\
\hline III/IV & $84(42 \%)$ & $34(49 \%)$ & $46(39 \%)$ & \\
\hline \multicolumn{5}{|l|}{ Extranodal sites } \\
\hline Fewer than two & $152(77 \%)$ & $52(74 \%)$ & $92(79 \%)$ & 0.59 \\
\hline Two or more & $46(23 \%)$ & $18(26 \%)$ & $25(21 \%)$ & \\
\hline \multicolumn{5}{|l|}{ Karnofsky score } \\
\hline Higher than 70 & $161(81 \%)$ & $55(79 \%)$ & $96(81 \%)$ & 0.71 \\
\hline 70 or lower & $38(19 \%)$ & $15(21 \%)$ & $22(19 \%)$ & \\
\hline \multicolumn{5}{|l|}{$L D H$} \\
\hline Normal & $108(56 \%)$ & $37(55 \%)$ & $64(56 \%)$ & 1.00 \\
\hline High & $84(44 \%)$ & $30(45 \%)$ & $51(44 \%)$ & \\
\hline \multicolumn{5}{|l|}{ B symptoms } \\
\hline No & $142(72 \%)$ & $43(62 \%)$ & $90(77 \%)$ & 0.04 \\
\hline Yes & $55(28 \%)$ & $26(38 \%)$ & $27(23 \%)$ & \\
\hline \multicolumn{5}{|l|}{ IPI risk group } \\
\hline Low $(0-2)$ & $126(66 \%)$ & 39 (58\%) & $79(69 \%)$ & 0.15 \\
\hline High (3-5) & $65(34 \%)$ & $28(42 \%)$ & $35(31 \%)$ & \\
\hline
\end{tabular}

LDH, serum lactate dehydrogenase; IPI, International Prognostic Index.

${ }^{\mathrm{a}}$ PKC- $\beta$ staining was evaluable in 187 cases; an additional two cases were positive for cyclin D2 but not evaluable for PKC- $\beta$.

${ }^{\mathrm{b}}$ Although the median age and age range are nearly identical, the age distribution of the negative group showed a slightly older tendency.

months for those lacking both markers (Figure 2a). Furthermore, when used together, expression of either cyclin D2 or PKC- $\beta$ is an independent predictor of worse overall survival.

Cyclin D2 is a cell cycle regulatory protein that facilitates the G1 to S phase transition. By immunohistochemistry, cyclin D2 expression has been reported to occur in $14 \%$ of DLBCL. ${ }^{23}$ Similarly, we found that $19 \%$ of our cases were positive for cyclin D2. In the current study, we also found that expression of cyclin D2 was associated with a significantly worse overall survival $(P=0.025)$. We were the first to report, in a different group of patients with DLBCL and gene expression profiling data, that cyclin D2 expression predicts for worse survival in DLBCL and that it is limited to DLBCL with an activated B-cell-like or unclassified gene expression profile. ${ }^{23}$ No other studies evaluating the prognostic significance of cyclin D2 expression in DLBCL have been published.
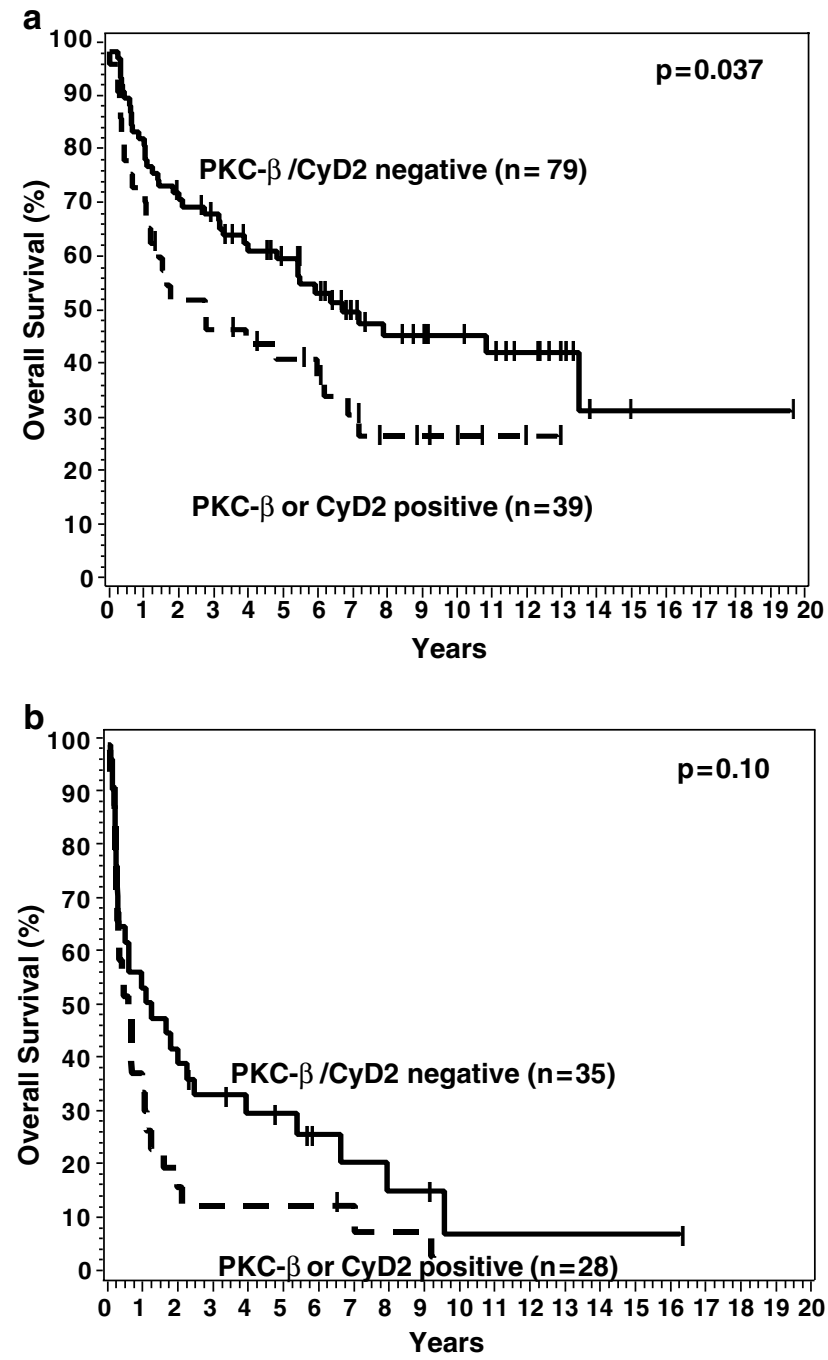

Figure 4 Expression of either PKC- $\beta$ or cyclin D2 (CyD2) within IPI groups in DLBCL. (a) Overall survival of patients with low IPI scores (0-2); (b) overall survival of patients with high IPI scores (3-5).

We also studied the expression of cyclin D3, another member of this gene family, but found that it had no effect on survival in DLBCL. Another study found that aggressive B-cell lymphomas with cyclin D3 expression showed a trend towards worse overall survival, but this did not reach statistical significance. ${ }^{18}$ In contrast, a single study has reported that cyclin D3 predicts for worse overall survival in DLBCL. ${ }^{20}$ Although the cyclin D3-positive cases in that study were significantly more likely to have higher stage (III or IV) disease, more extranodal sites, and higher IPI scores, multivariate analysis showed cyclin D3 expression to be an independent adverse prognostic factor.

PKC- $\beta$ is a protein kinase that is involved in signal transduction and plays an important role in B-cell receptor signaling. ${ }^{24,25}$ In a group of patients with DLBCL evaluated by an oligonucleotide microarray, PKC- $\beta$ was one member of a 13 gene predictor of 
outcome. ${ }^{6}$ Shipp et $a l^{6}$ also found that an immunoperoxidase stain for PKC- $\beta$ correlated with the amount of transcript determined by oligonucleotide microarray analysis. Furthermore, those cases expressing PKC- $\beta$ by immunohistochemistry had a significantly worse overall survival. However, immunostains for PKC- $\beta$ were graded similar to the microarray results in that study and, therefore, a quantitative cut-point was not determined. In our study, we used the same monoclonal antibody and our results (22\% positive) are comparable to their finding of PKC- $\beta$ expression in $38 \%$ of DLBCL by immunoperoxidase staining. Another immunohistochemical study reported that PKC- $\beta$ is expressed in $71 \%$ of DLBCL. ${ }^{26}$ However, we found PKC- $\beta$ expression in greater than $50 \%$ of tumor cells in only $22 \%$ of our cases. There was no mention of the cut-point used to determine positivity and this study ${ }^{26}$ used a different monoclonal antibody that was raised against PKC- $\beta$ from rabbit brain, which may not have the same reactivity as the mouse monoclonal antibody (clone 28) that was used in our study.

None of the other markers that we evaluated were predictive of survival in this group of patients with DLBCL. Numerous studies have been published on these markers and most show conflicting results. Bcl-2 has been studied extensively in DLBCL and the results are controversial. Multiple studies have looked at the expression of bcl-2 using immunostains and most have found no difference in overall survival. ${ }^{16,23,27-35}$ However, some studies have found that bcl-2 expression is associated with a significantly worse overall survival,,36-42 or event-free survival. ${ }^{29-31,36,37}$ The discrepancies related to bcl-2 expression and prognosis may be related to the underlying subgroups of DLBCL. Within the nongerminal center B-cell-like subgroup of DLBCL, bcl2 expression is associated with a significantly worse overall survival and event-free survival, whereas bcl-2 expression is not predictive of survival within the germinal center B-cell-like subgroup. ${ }^{23,43,44}$ Similarly, MUM1 has been reported to be associated with worse overall survival by some investigators, ${ }^{23,43,44}$ but was not found to be predictive by others. ${ }^{42}$ Uniform high expression of FoxP1 has been associated with a poor outcome ${ }^{45}$ Although we used a cut-point of $30 \%$ for FOXP1, we evaluated all cutpoints for significance using a survival tree method and none were significant. In addition, we specifically compared overall survival of those with $100 \%$ FOXP1 expression (28\% of cases) to those with less than $100 \%$ FOXP1 expression. Although there was a trend toward worse overall survival in the $100 \%$ FOXP1 group, the difference was not significant $(P=0.16)$. Studies on the predictive value of Ki-67 expression are also conflicting and the positive cutpoints in DLBCL vary dramatically between studies, ranging from 10 to $80 \%$. Expression of Ki-67 has been associated with significantly worse overall survival, ${ }^{31,46-49}$ significantly better overall survival, ${ }^{50-52}$ or to have no effect on overall survival in
DLBCL. ${ }^{16,32,53,54}$ Although we initially used a cutpoint of $50 \%$ for Ki-67, we analyzed all possible cut-points using a survival tree method and found no value that had a statistically significant effect on overall survival or event-free survival. ${ }^{13}$ A single study has reported that survivin expression is an independent predictor of worse survival in DLBCL. ${ }^{21}$ Similar to that study, in which $60 \%$ of the cases were positive, we found survivin expression in $65 \%$ of our group. Despite this similarity, we did not find any prognostic effect of survivin expression in DLBCL.

Given the variability of outcomes in these retrospective studies, it is doubtful that any individual marker can be used consistently to predict survival in DLBCL. In addition, although individual genes may be highly predictive of outcome in gene expression studies, no single gene accurately subclassifies all cases of DLBCL. ${ }^{6,7}$ Therefore, a number of markers need to be combined to form a 'biological prognostic index' which will predict survival in DLBCL, using either gene expression or protein expression methodologies. When used alone or in combination, we found that expression of cyclin D2 or PKC- $\beta$ identifies a group of patients with significantly worse overall survival and event-free survival. Furthermore, in multivariate analysis, the combination of these two markers was an independent adverse predictor of survival in our patients with DLBCL. Additional studies are needed to confirm our findings. In addition, studies of these markers in DLBCL patients treated with rituximab will be important to evaluate whether rituximab affects outcome. Inhibitors of PKC are being used in clinical trials of patients with relapsed or progressive non-Hodgkin's lymphoma. ${ }^{55-57}$ If our findings are confirmed, the addition of PKC inhibitors to initial chemotherapy regimens should be considered in clinical trials of this group of patients with DLBCL. As additional immunohistochemical markers of aggressive disease are identified through gene expression studies, our findings suggest that cyclin D2 and PKC- $\beta$ should be included with these new markers to form a 'biological prognostic index' that could be used in clinical trials to stratify patients for risk-adjusted therapies.

\section{Acknowledgements}

We thank Dr Alison Banham for the FOXP1 antibody and Dr Brunangelo Falini for the MUM1p antibody. This work was supported in part by US Public Health Service grants CA36727 and CA84967 awarded by the National Cancer Institute, Department of Health and Human Services.

\section{Duality of interest}

None declared. 


\section{References}

1 A clinical evaluation of the International Lymphoma Study Group classification of non-Hodgkin's lymphoma. The Non-Hodgkin's Lymphoma Classification Project. Blood 1997;89:3909-3918.

2 Coiffier B. Diffuse large cell lymphoma. Curr Opin Oncol 2001;13:325-334.

3 Mounier N, Briere J, Gisselbrecht C, et al. Rituximab plus CHOP (R-CHOP) overcomes bcl-2-associated resistance to chemotherapy in elderly patients with diffuse large B-cell lymphoma (DLBCL). Blood 2003; 101:4279-4284.

4 A predictive model for aggressive non-Hodgkin's lymphoma. The International Non-Hodgkin's Lymphoma Prognostic Factors Project. N Engl J Med 1993; 329:987-994.

5 Alizadeh AA, Eisen MB, Davis RE, et al. Distinct types of diffuse large B-cell lymphoma identified by gene expression profiling. Nature 2000;403:503-511.

6 Shipp MA, Ross KN, Tamayo P, et al. Diffuse large Bcell lymphoma outcome prediction by gene-expression profiling and supervised machine learning. Nat Med 2002;8:68-74.

7 Rosenwald A, Wright G, Chan WC, et al. The use of molecular profiling to predict survival after chemotherapy for diffuse large B-cell lymphoma. N Engl J Med 2002;346:1937-1947.

8 Rosenwald A, Wright G, Leroy $\mathrm{K}$, et al. Molecular diagnosis of primary mediastinal $B$ cell lymphoma identifies a clinically favorable subgroup of diffuse large B cell lymphoma related to Hodgkin lymphoma. J Exp Med 2003;198:851-862.

9 Savage KJ, Monti S, Kutok JL, et al. The molecular signature of mediastinal large B-cell lymphoma differs from that of other diffuse large B-cell lymphomas and shares features with classical Hodgkin lymphoma. Blood 2003;102:3871-3879.

10 Wright G, Tan B, Rosenwald A, et al. A gene expression-based method to diagnose clinically distinct subgroups of diffuse large B cell lymphoma. Proc Natl Acad Sci USA 2003;100:9991-9996.

11 Vose J, Anderson J, Bierman P, et al. Comparison of front-line chemotherapy for aggressive non-Hodgkin's lymphoma using the CAP-BOP regimens. Sem Hematol 1994;31(Suppl 3):4-8.

12 Vose J, Weisenburger D, Lynch J, et al. CNOP for diffuse aggressive non-hodgkin's lymphoma: the Nebraska lymphoma study group experience. Leuk Lymph 2002;43:799-804.

13 LeBlanc M, Crowley J. Survival trees by goodness of split. J Am Stat Assoc 1993;88:457-467.

14 Hans CP, Weisenburger DD, Gascoyne RD, et al. Classification of diffuse large B-cell lymphoma into prognostically significant subgroups by immunohistochemistry using a tissue microarray [abstract]. Mod Pathol 2002;15:243a.

15 Hans CP, Weisenburger DD, Greiner TC, et al. Confirmation of the molecular classification of diffuse large B-cell lymphoma by immunohistochemistry using a tissue microarray. Blood 2004;103:275-282.

16 Hedvat CV, Hegde A, Chaganti RS, et al. Application of tissue microarray technology to the study of nonHodgkin's and Hodgkin's lymphoma. Hum Pathol 2002;33:968-974.

17 Llanos M, Alvarez-Arguelles $\mathrm{H}$, Aleman $\mathrm{R}$, et al. Prognostic significance of Ki-67 nuclear proliferative antigen, bcl-2 protein, and p53 expression in follicular and diffuse large B-cell lymphoma. Med Oncol 2001;18:15-22.

18 Kaplan E, Meier P. Nonparametric estimation from incomplete observations. Am Stat Assoc J 1958;53: 457-481.

19 Cox D. Regression models and life-tables. J R Stat Soc 1972;34:187-220.

20 Moller MB, Nielsen O, Pedersen NT. Cyclin D3 expression in non-Hodgkin lymphoma. Correlation with other cell cycle regulators and clinical features. Am J Clin Pathol 2001;115:404-412.

21 Filipits M, Jaeger U, Pohl G, et al. Cyclin D3 is a predictive and prognostic factor in diffuse large B-cell lymphoma. Clin Cancer Res 2002;8:729-733.

22 Adida C, Haioun C, Gaulard P, et al. Prognostic significance of survivin expression in diffuse large Bcell lymphomas. Blood 2000;96:1921-1925.

23 Teramoto N, Pokrovskaja K, Szekely L, et al. Expression of cyclin D2 and D3 in lymphoid lesions. Int J Cancer 1999;81:543-550.

24 Wetsel WC, Khan WA, Merchenthaler I, et al. Tissue and cellular distribution of the extended family of protein kinase C isoenzymes. J Cell Biol 1992;117:121-133.

$25 \mathrm{Su}$ TT, Guo B, Kawakami Y, et al. PKC-beta controls I kappa B kinase lipid raft recruitment and activation in response to BCR signaling. Nat Immunol 2002;3: 780-786.

26 Hojo H, Morimura Y, Abe M, et al. Expression of classical protein kinase $\mathrm{C}$ subspecies in non-neoplastic lymphocytes and non-Hodgkin's lymphomas: an immunohistochemical study. Pathol Int 1996;46: 148-154.

27 Piris MA, Pezzella F, Martinez-Montero JC, et al. p53 and bcl-2 expression in high-grade B-cell lymphomas: correlation with survival time. Br J Cancer 1994;69: 337-341.

28 Tang SC, Visser L, Hepperle B, et al. Clinical significance of bcl-2-MBR gene rearrangement and protein expression in diffuse large-cell non-Hodgkin's lymphoma: an analysis of 83 cases. J Clin Oncol 1994; 12:149-154.

29 Kramer MH, Hermans J, Parker J, et al. Clinical significance of bcl2 and p53 protein expression in diffuse large B-cell lymphoma: a population-based study. J Clin Oncol 1996;14:2131-2138.

30 Hill ME, MacLennan KA, Cunningham DC, et al. Prognostic significance of BCL-2 expression and bcl-2 major breakpoint region rearrangement in diffuse large cell non-Hodgkin's lymphoma: a British National Lymphoma Investigation Study. Blood 1996; 88:1046-1051.

31 Sanchez E, Chacon I, Plaza MM, et al. Clinical outcome in diffuse large B-cell lymphoma is dependent on the relationship between different cell-cycle regulator proteins. J Clin Oncol 1998;16:1931-1939.

32 Zhang A, Ohshima K, Sato K, et al. Prognostic clinicopathologic factors, including immunologic expression in diffuse large B-cell lymphomas. Pathol Int 1999;49:1043-1052.

33 Harada S, Suzuki R, Uehira K, et al. Molecular and immunological dissection of diffuse large $\mathrm{B}$ cell lymphoma: CD5+, and CD5- with CD10+ groups may constitute clinically relevant subtypes. Leukemia 1999;13:1441-1447.

34 Takeshita M, Iwashita A, Kurihara K, et al. Histologic and immunohistologic findings and prognosis of 40 
cases of gastric large B-cell lymphoma. Am J Surg Pathol 2000;24:1641-1649.

35 Sohn SK, Jung JT, Kim DH, et al. Prognostic significance of bcl-2, bax, and p53 expression in diffuse large B-cell lymphoma. Am J Hematol 2003;73:101-107.

36 Hermine O, Haioun C, Lepage E, et al. Prognostic significance of bcl-2 protein expression in aggressive non- Hodgkin's lymphoma. Groupe d'Etude des Lymphomes de l'Adulte (GELA). Blood 1996;87:265-272.

37 Gascoyne RD, Adomat SA, Krajewski S, et al. Prognostic significance of Bcl-2 protein expression and Bcl-2 gene rearrangement in diffuse aggressive nonHodgkin's lymphoma. Blood 1997;90:244-251.

38 Kramer $\mathrm{MH}$, Hermans J, Wijburg E, et al. Clinical relevance of BCL2, BCL6, and MYC rearrangements in diffuse large B-cell lymphoma. Blood 1998;92:3152-3162.

39 Rantanen S, Monni O, Joensuu H, et al. Causes and consequences of BCL2 overexpression in diffuse large B-cell lymphoma. Leuk Lymphoma 2001;42:1089-1098.

40 Barrans SL, Carter I, Owen RG, et al. Germinal center phenotype and bcl-2 expression combined with the International Prognostic Index improves patient risk stratification in diffuse large B-cell lymphoma. Blood 2002;99:1136-1143.

41 Barrans SL, O’Connor SJ, Evans PA, et al. Rearrangement of the BCL6 locus at 3q27 is an independent poor prognostic factor in nodal diffuse large B-cell lymphoma. Br J Haematol 2002;117:322-332.

42 Colomo L, Lopez-Guillermo A, Perales $\mathrm{M}$, et al. Clinical impact of the differentiation profile assessed by immunophenotyping in patients with diffuse large B-cell lymphoma. Blood 2003;101:78-84.

43 Trzpuc T, Kampalath B, Abed N, et al. Expression of MUM1/IRF4 Correlates with Prognosis in Patients with Diffuse Large B-cell Lymphoma [abstract]. Mod Pathol 2002;15:267a.

44 Chang CC, McClintock S, Cleveland RP, et al. Immunohistochemical expression patterns of germinal center and activation B-cell markers correlate with prognosis in diffuse large B-cell lymphoma. Am J Surg Pathol 2004;28:464-470.

45 Barrans SL, Fenton JA, Banham A, et al. Strong expression of FOXP1 identifies a distinct subset of diffuse large B-cell lymphoma patients with poor outcome. Blood 2004;104:2933-2935.

46 Grogan TM, Lippman SM, Spier CM, et al. Independent prognostic significance of a nuclear proliferation antigen in diffuse large cell lymphomas as determined by the monoclonal antibody Ki-67. Blood 1988;71: 1157-1160.
47 Slymen DJ, Miller TP, Lippman SM, et al. Immunobiologic factors predictive of clinical outcome in diffuse large-cell lymphoma. J Clin Oncol 1990;8: 986-993.

48 Miller TP, Grogan TM, Dahlberg S, et al. Prognostic significance of the Ki-67-associated proliferative antigen in aggressive non-Hodgkin's lymphomas: a prospective Southwest Oncology Group trial. Blood 1994;83:1460-1466.

49 Saez A, Sanchez E, Sanchez-Beato M, et al. p27KIP1 is abnormally expressed in diffuse large B-cell lymphomas and is associated with an adverse clinical outcome. Br J Cancer 1999;80:1427-1434.

50 Gerdes J, Stein H, Pileri S, et al. Prognostic relevance of tumour-cell growth fraction in malignant non-Hodgkin's lymphomas. Lancet 1987;2:448-449.

51 Hall PA, Richards MA, Gregory WM, et al. The prognostic value of Ki67 immunostaining in nonHodgkin's lymphoma. J Pathol 1988;154:223-235.

52 Kossakowska AE, Huchcroft S, Boras V, et al. Prognostic significance of proliferative activity of diffuse large cell lymphomas. Hematol Pathol 1991;5:101-107.

53 Nakamine H, Bagin RG, Vose JM, et al. Prognostic significance of clinical and pathologic features in diffuse large B-cell lymphoma. Cancer 1993;71: 3130-3137.

54 Seki R, Okamura T, Koga H, et al. Prognostic significance of the F-box protein Skp2 expression in diffuse large B-cell lymphoma. Am J Hematol 2003; 73:230-235.

55 Varterasian ML, Mohammad RM, Eilender DS, et al. Phase I study of bryostatin 1 in patients with relapsed non-Hodgkin's lymphoma and chronic lymphocytic leukemia. J Clin Oncol 1998;16:56-62.

56 Blackhall FH, Ranson M, Radford JA, et al. A phase II trial of bryostatin 1 in patients with non-Hodgkin's lymphoma. Br J Cancer 2001;84:465-469.

57 Dowlati A, Lazarus HM, Hartman P, et al. Phase I and correlative study of combination bryostatin 1 and vincristine in relapsed B-cell malignancies. Clin Cancer Res 2003;9:5929-5935.

58 Falini B, Fizzotti M, Pucciarini A, et al. A monoclonal antibody (MUM1p) detects expression of the MUM1/ IRF4 protein in a subset of germinal center B cells, plasma cells, and activated T cells. Blood 2000;95: 2084-2092.

59 Banham AH, Beasley N, Campo E, et al. The FOXP1 winged helix transcription factor is a novel candidate tumor suppressor gene on chromosome 3p. Cancer Res 2001;61:8820-8829. 